4. Schneider G. Fremdsprachenforschung und die Ausbildung von Fremdsprachenlehrerinnen und -lehrern / Beiträge zur Lehrerbildung, 25 (2). - 2007. - S. 143-155. - [Електронний ресурс]. - Режим доступу: http://www.bzl-online.ch 5. Universität Zürich. E-Learning Koordination der Philosophischen Fakultät. Grundformen der E-Learning. - [Електронний pecypc]. - Режим доступу: www.phil.uzh.ch/ fakultaet/elearning/definition/Grundfomen_von_El.pdf ДВНЗ «Криворізький національний університет»

\title{
ПСИХОЛОГО-ПЕДАГОГІЧНІ ОСНОВИ ВИЗНАЧЕННЯ ЗМІСТУ І СТРУКТУРИ ПЕДАГОГІЧНОГО ТЕСТУ
}

Статтю присвячено узагальненню основних психолого-педагогічних підходів до визначення змісту і структури педагогічного тесту. Наведено класифікацію основних форм тестових завдань як структурної одиниці тесту. Розглянуто переваги та недоліки тестових завдань, а також формальні, статистичні й психолого-педагогічні вимоги щодо їх включення до складу педагогічного тесту.

Ключові слова: педагогічний тест, завдання в тестовій формі, тестове завдання, завдання відкритого типу, завдання закритого типу.

Статья посвящена обобщению основных психолого-педагогических подходов к определению содержания и структуры педагогического теста. Приведена классификация основных форм тестовых заданий как структурной единиць теста. Рассмотрень преимущества и недостатки тестовых заданий, а также формальные, статистические и психологопедагогические требования по их включению в состав педагогического mecma.

Ключевые слова: педагогический тест, задание в тестовой форме, тестовое задание, задания открытого типа, задания закрытого типа.

The article is dedicated to the generalization of the main psychopedagogical approaches to the determination of the pedagogical test content and structure. The classification of test questions main types as a test structural unit is supplied. The merits and demerits of test questions and also formal, statistical and psycho-pedagogical requirements for their inclusion to the pedagogical test content are considered.

Key words: pedagogical test, test-like questions, test question, essay question, objective question.

В умовах модернізації змісту сучасної системи вищої освіти України застосування тестування як засобу педагогіч- 
ного моніторингу та методу вимірювання і оцінювання навчальних досягнень студентів на всіх етапах навчальної діяльності особливої актуальності набуває питання якості засобів педагогічної тестової діагностики. Нагальним $\epsilon$ розв'язання питань забезпечення валідності та надійності педагогічних тестів як об'єктивного інструменту педагогічних вимірювань, подальшої розробки психолого-педагогічних, дидактичних та методичних принципів створення тестових завдань відповідно до цілей та змісту навчання, процедури проведення тестування та оцінювання його результатів 3 метою найефективнішого їх використання у процесі забезпечення якості вищої освіти.

У сучасній тестології розробці загальних психологопедагогічних принципів конструювання педагогічного тесту, визначенню його змісту і структури присвячено роботи багатьох зарубіжних (Р. Ібел, П. Айразіан, Р. Трондайк, Р. Арендз, Н. Грунлунд), російських (В. Аванесов, О. Майоров, М. Челишкова, В. Кім, В. Звонніков) та вітчизняних науковців (А. Кузьмінський, В. Сфіменко, І. Булах, Т. Лукіна та ін.).

Mema cmammi: узагальнити провідні психологопедагогічні підходи до визначення змісту і структури педагогічного тесту; розглянути основні психолого-педагогічні, формальні та статистичні вимоги до його структурної одиниці тестового завдання - у розмаїтті форм представлення.

На сучасному етапі розвитку педагогічної теорії і практики тестування посідає чільне місце серед інших засобів контролю та діагностики навчальних досягнень студентів як стандартизований та об'єктивний метод педагогічних вимірювань, що має під собою грунтовну теоретичну базу.

За визначенням М. Челишкової педагогічне вимірювання - це процес встановлення відповідності між характеристиками тих, кого навчають, що оцінюються, і точками емпіричної шкали, у якій відношення між різними оцінками характеристик виражено через властивості числового ряду. Роль одиниці вимірювання виконують тестові завдання, об'єктом оцінювання є самі учні, а результатом вимірювання - шкала балів тих, кого навчають [7, с. 63]. Складність отримання точних і об'єктивних результатів педагогічного вимірювання полягає у тому, що сам процес вимірювання $є$ свого роду опосередкованим, оскільки об'єктами вимірювання є латентні характеристики такі як знання,уміння, навички, компетенції. Тож оцінюванню піддаються не власне характеристики, а 
їх емпіричні референти - ознаки характеристик, що спостерігаються.

Саме 3 цих причин надзвичайно важливим $є$ дотримання визначених сучасною тестологією принципів добору, конструювання та застосування тестів та тестових завдань відповідно до цілей педагогічного вимірювання і згідно з цілями і змістом навчального процесу.

Виокремлюють такі основні психолого-педагогічні принципи педагогічних вимірювань:

- взаємозв'язку педагогічних вимірювань і цілей освіти та навчання;

- об'єктивності вимірювань;

- справедливості;

- науковості та ефективності;

- систематичності;

- гуманності та етичності [2].

Як зазначає В. Аванесов, у теорії педагогічних вимірювань вихідним $є$ поняття «педагогічне завдання», що може бути сформульоване як в тестовій, так і в нетестовій формі. Прикладами завдань нетестової форми є питання, задача, навчальна проблема тощо. Найбільш ефективною та коректною формою педагогічних вимірювань уважають завдання у тестовій формі і сформовані з них за певною методикою педагогічні тести. [6, с. 4]. До таких завдань висувають такі формальні вимоги: стислість, правильність вибору форми, логічна форма висловлювання, однаковість правил оцінювання відповідей, наявність певного місця для відповідей, правильність розташування елементів завдання, однаковість інструкції для всіх випробуваних, адекватність інструкції формі і змісту завдання [1, с. 9]

Мінімальними структурними компонентами завдання в тестовій формі або тестового завдання $є$ інструкція, що містить чіткі вказівки щодо способу виконання завдання; текст завдання, що є змістовим наповненням завданням; правильною відповіддю або оціночною схемою [4, с. 77-80].

У теорії педагогічних вимірювань розрізняють поняття «завдання в тестовій формі» та «тестові завдання». При однаковості форми подання, різниця між цими завданнями полягає у відповідності статистичним вимогам до тестових завдань, а саме: 1) складності завдання; 2) диференційній властивості; 3) позитивній кореляції балів завдання з сумарними балами всього тесту [6, с. 8$]$. 
Тобто завдання в тестовій формі має пройти певну перевірку статистичних якостей для подальшого включення його до складу педагогічного тесту. Тестові завдання є складовими одиницями тесту, що відповідають вимогам технологічності, форми, змісту, і статистичним вимогам і відрізняються за формою. Під формою тестового завдання розуміють таке розташування елементів, яке найбільш ефективно забезпечує можливість реалізувати функцію контролю або навчання [3].

Більшість дослідників теорії тестології (В. Аванесов, I. Булах, Т. Лукіна та ін.) вважають, що основними є чотири форми тестових завдань:

- закритого типу з вибором однієї чи кількох правильних відповідей із запропонованих варіантів вибору;

- відкритого типу як форми, що не містить готової відповіді. Для об'єктивного оцінювання правильності виконання таких завдань необхідною є розробка чітких критеріїв оцінювання;

- на встановлення відповідності між елементами двох різних множин;

- на встановлення правильної послідовності.

Однак існує дещо інший погляд на класифікацію тестових завдань. У роботі [8] зазначається, що основними формами тестових завдань, що використовуються у сучасній педагогіці США, є тести-есе та об'єктивні тести. Термін essay question («екзаменаційне питання» або завдання відкритого типу) широко використовується для означення всіх питань, що передбачають відповідь у вільній формі, з урахуванням питань, що вимагають від екзаменованого не тільки розгорнутих відповідей (подібно до творів чи есе), але й таких, на які він повинен дати коротку словесну або числову (наприклад, у вигляді розв'язання математичної задачі) відповідь. На противагу тестам-есе «об' єктивні питання» (objective questions або завдання закритого типу) вимагають відповіді із запропонованих альтернатив [8, с. 14].

Того ж принципу у класифікації тестових завдань дотримується А. Майоров, поділяючи тестові завдання на завдання відкритого типу, до яких відносить завдання з доповненням i завдання довільного викладу, і завдання закритого типу, що поділяються на завдання альтернативного вибору, множинного вибору, встановлення відповідності, встановлення правильної послідовності [4 с. 83]. 
Уважаємо, що включення завдань на встановлення відповідності та на встановлення правильної послідовності до групи тестових завдань закритого типу є достатньо обгрунтованим; незважаючи на відмінність цих форм завдань від завдань 3 вибором у характері дій, необхідних для їх виконання, вони подібні за характером подання навчальної інформації, а саме іiї повнотою та істинністю, тобто не потребує від того, кого тестують, внесення додаткової інформації, яка не зазначена в самому завданні, для його виконання.

Завдання відкритої форми поділяються на завдання 3 доповненням і завдання 3 розгорнутою відповіддю у вигляді довільного викладу. У першому випадку ті, кого тестують, повинні самостійно дати відповідь на питання, однак їх можливості обмежені. Обмеження забезпечують об'єктивність оцінювання результатів виконання завдання [4, с. 99]. Зазвичай доповнення має бути коротким - від одного до трьох слів. Завдання $з$ розгорнутою відповіддю потребує побудови письмового висловлювання з обгрунтованим доведенням (через ствердження чи спростування) запропонованої тези. В таких завданнях оцінюванню підлягають не лише знання окремих фактів, а й логічність викладу, здатність до критичного мислення, інтерпретування ідей, узагальнення.

Для створення педагогічних тестів найчастіше використовують завдання закритого типу. Це пояснюється більшою, порівняно з завданнями відкритої форми, об'єктивністю оцінювання, технологічністю, простотою алгоритму виконання завдання, можливістю машинної обробки.

Основним видом завдань закритого типу є завдання множинного вибору, що передбачають наявність варіативності у виборі, тобто вибір однієї правильної відповіді з запропонованих варіантів [4, с. 87]. Незважаючи на недоліки цього типу завдань, серед яких трудомісткість складання якісних завдань множинного вибору, що пов'язана зі складністю добору адекватних дистракторів (правдоподібних помилкових варіантів відповіді), більшість західних фахівців уважає їх найкращою формою тестових завдань, що можуть ефективно використовуватися не тільки для вимірювання здатності пригадувати, але й для вимірювання таких важливих навчальних результатів, як уміння робити оцінні судження, розв'язувати проблеми, аналізувати, синтезувати, виконувати певні дії, прогнозувати тощо [8, с. 17]. 
Завдання альтернативного вибору пропонують лише одну альтернативу, тобто лише два варіанти відповідей: «так - ні», «правильно - неправильно». Вони $є$ малоефективними через велику ймовірність вгадування, за виключенням ситуації, коли використовується серія завдань цього типу для оцінювання одного елементу знань [4, с. 84].

У завданнях на встановлення відповідності пропонується розташувати елементи однієї множини відповідно до елементів іншої множини. Такі завдання дозволяють перевірити асоціативні знання - про взаємозв'язок визначень і фактів, форм і змісту, сутності та явищ і т. д. [6, с. 28].

Завдання на послідовність дозволяють перевірити здатність до алгоритмічного мислення, знання, уміння, навички 3 встановлення правильної послідовності різних дій, операцій, розрахунків, термінів, визначень і т. д. [6, с. 30].

У процесі укладання якісного педагогічного тесту необхідним є дотримання певних психолого-педагогічних вимог до конструювання та добору тестових завдань, що входять до його складу, а саме:

- Тестові завдання не повинні містити помилкових (неперевірених, недостовірних, неточних) даних. Порушення цієї вимоги може призвести до конфліктної ситуації, несерйозного ставлення студентів до процедури тестування, $\mathrm{i}$, що $\epsilon$ не припустимим, накопичення у пам'яті студентів помилкової інформації.

- Кожне тестове завдання повинно передбачати однозначно правильну відповідь (якщо це тип завдання з вибором однієї правильної відповіді з кількох запропонованих варіантів).

- Тестові завдання повинні бути складені так, щоб результати тестування визначали рівень знань лише із даного предмету (ця вимога не стосується абсолютно гетерогенних тестів, в яких вимірюється рівень знань 3 декількох дисциплін).

- При складанні тестових завдань потрібно максимально знизити вірогідність «вгадування» правильної відповіді. 3 цією метою необхідно зменшити кількість завдань на вибір правильної відповіді із запропонованих варіантів (найбільш оптимальною кількістю є 3-4) та використовувати більше завдань відкритого типу, завдань на відповідність та встановлення правильної послідовності. 
- До кожного завдання повинна бути адекватна інструкція відповідно до його форми та змісту.

Що стосується вимог до кожного типу тестових завдань зокрема, то до завдань відкритої форми можна виокремити такі:

- доповнююче слово чи словосполучення потрібно розташовувати в кінці твердження;

- у доповненні повинна міститись важлива інформація;

- бажано при формулюванні завдань доповнення ставити у називному відмінку;

- завдання рекомендується формулювати так, щоб відповідь складалася 3 двох-трьох слів;

- потрібно дати студентові зразок відповіді на тестове завдання цього типу.

Закрита форма тестових завдань (тестові завдання з вибором правильної відповіді із кількох запропонованих) повинна відповідати таким вимогам: 1) однакова правдоподібність варіантів відповіді; не рекомендовано пропонувати явно правдоподібні варіанти для вибору правильної відповіді, які студент може розпізнати без особливих розумових зусиль; неправильні варіанти повинні звучати правдоподібно; 2) у варіантах вибору необхідно використовувати однакову кількість об'єктів, бажано один; 3) потрібно уникати повторення слів у відповідях; 4) важливо, щоб інформаціях у твердженнях певних завдань не містила відповідь на попередні завдання.

У тестових завданнях на встановлення правильної послідовності потрібно визначити принципи формування елементів. Загальноприйнятим $є$ принцип алфавітного порядку. Проте, якщо алфавітне розташування є правильним варіантом, потрібно розмістити елементи у довільному порядку.

Однією $з$ вимог-пропозицій до тестових завдань на встановлення відповідності $€$ формування множини варіантів для вибору на 1, 2 або три елементи більше, ніж у множині для відповіді. Це необхідно робити для того, щоб під час останньої підстановки у студента був вибір, а не автоматичний залишок для підстановки [5, с. 108-109].

Вимірювання рівня знань, умінь і навичок студентів $\epsilon$ важливим елементом навчального процесу вищої школи. Найефективнішим технологічним та об'єктивним засобом педагогічних вимірювань визнано тест. Результати вимірювання, отримані в процесі тестування навчальних досягнень студентів, можуть активно використовуватись у системі за- 
безпечення якості навчання. Однак важливою умовою отримання адекватних та об'єктивних результатів є якість інструментарію педагогічного вимірювання, тобто власне тесту та його структурних одиниць - тестових завдань.

Кожен тест створюється саме системою завдань. Основними формами тестових завдань $є$ завдання відкритої та закритої форми. Кожен 3 цих видів завдань має свої переваги та недоліки, однак обидва можуть бути ефективно використані для вимірювання будь-якого навчального досягнення, за умови виконання ряду психолого-педагогічних, а саме: відповідності форми і змісту тестових завдань меті педагогічного вимірювання та змісту навчального предмету, курсу, оптимального рівня складності, застосування чітких та об'єктивних критеріїв оцінювання виконання завдання, використання в завданнях закритого типу якісних дистракторів та обов'язкова наявність правильної відповіді; формальних, що стосуються форми представлення завдання, логічності викладу, наявності, правильної послідовності та відповідності структурних компонентів завдання; статистичних, серед яких складність, диференційна властивість, позитивна кореляція балів завдання з сумарними балами всього тесту, вимог до тестових завдань. Вибір певної форми тестового завдання підпорядковується меті тестування, змісту навчальної теми, предмету, технічним можливостям тощо. Оптимальним уважається поєднання різних форм тестових завдань 3 метою мінімізації можливості вгадування, що є характерним недоліком завдань множинного вибору.

\section{Література}

1. Аванесов В. С. Композиция тестовых заданий : [учеб. книга] / Вадим Сергеевич Аванесов. - [3 изд., доп.]. - М. : Центр тестирования, 2002. - 240 с. 2. Аванесов В. С. Определение, предмет и основные функции педагогической диагностики / Вадим Сергеевич Аванесов // Педагогическая диагностика. - 2002. - № 1. - С. 32-46. 3. Аванесов В. С. Понятийный аппарат педагогической тестологии / Вадим Сергеевич Аванесов // Педагогическая диагностика. 2002. - №2. - С. 34 - 46. 4. Майоров А. Н. Теория и практика создания тестов для системы образования. (Как выбирать, создавать и использовать тесты для целей образования) / Алексей Николаевич Майоров. - М. : Интеллект-центр, 2001. - 296 с. 5. Морська Л. І. Теоретико-методологічні основи розробки та застосування комп'ютерного педагогічного тесту : [монографія] / Лілія Іванівна Морська. - Тернопіль : Астон, 2006. - 160 с. 6. Педагогические тесты. Вопросы разработки и применения: пособие для преподавате- 
лей / В. С. Аванесов, Т. С. Хохлова, Ю. А. Ступак, О. Е. Потап, В. Г. Чернявский, С. А. Плискановский.- Дніпропетровськ : Пороги, 2005. - 64 с. 7. Челышкова М. Б. Теория и практика конструирования педагогических тестов : [учеб. пособ.] / М. Б. Челышкова. М. : Логос, 2002. - 432 с. 8. Чорна Н. В. Оцінювання навчальних досягнень учнів методом тестування в педагогіці США : автореф. дис. на здобуття наук. ступеня канд. пед. наук : 13.00.01 / Наталія Володимирівна Чорна; Житомир. держ. ун-т ім. І. Франка. - Житомир, 2005. -20 c.

О. Л. Пінська, кандидат пед. наук, доиент, Криворізький педагогічний інститут ДВНЗ «Криворізький начіональний університет»

\section{ОСОБЛИВОСТІ ПЕДАГОГІЧНОЇ ТВОРЧОСТІ ТА ФАКТОРИ ЇЇ РОЗВИТКУ В МАЙБУТНІХ ПЕДАГОГІВ}

У статті розкрито сутність та особливості педагогічної творчості, обгрунтовуються фактори, щуо детермінують ефективність ї̈ розвитку.

Ключові слова: творчість, педагогічна творчість, співтворчість, фактори розвитку творчості.

В статье раскрывается сущность и особенности педагогического творчества, обосновываются факторы, детерминируюшие эффективность ее развития.

Ключевые слова: творчество, педагогическое творчество, сотворчество, факторы развития творчества.

The article reveals the nature and characteristics of educational work, substantiate the factors that determine the effectiveness of its development.

Key words: art, teaching art, co-creation.

У парадигмі сучасної освіти вагомого значення надається формуванню творчої особистості, здатної самостійно мислити і приймати відповідальні рішення. Виховати таку особистість може вчитель, який продукує оригінальні ідеї, приймає нестандартні рішення у розв'язанні педагогічних проблем, здатний перебудовувати свою діяльність відповідно до вимог суспільства. Тому будь-яка педагогічна діяльність буде ефективною лише за умови реалізації в ній педагогічної творчості. Як свідчить практика, у більшості вчителів сучасної школи 